\title{
»Den stråtækte landsbyskole«
}

\author{
Minder fra Knud, Solderup og Rørkær
}

\section{Af Nina Langkilde}

I slutningen af 1950'erne blev de små én-, to- og tre-klassede landsbyskoler opslugt af det nye vidunder, centralskolerne. De små skoler levede kun videre $i$ erindringen, ofte som »den stråtækte skole«. Bogstaveligt talt var forholdene små i de gamle skoler. Siden er udviklingen gået så hurtigt, at det er svært at forstå, at der kun ligger henved 30 år mellem landsbyskolerne og vore dages skolepaladser.

Nina Langkilde oplevede den gamle landsbyskoles sidste tid, først som »lærerspire i Knud ved Haderslev, senere fra 1950 til december 1964 som enelærer i Solderup og Rørkær ved Tønder. I denne artikel tegner hun et levende billede af virkeligheden $\mathrm{i}$ »den stråtækte skole«.

\section{Skoler og skolestuer}

Forleden dag havde jeg ærinde på en af byens moderne skoler. Byggeriet er lavt, i ét plan. Gangene indenfor uendeligt lange, tæppebelagte; lokalerne store og lyse med muntre farver. Bordene forholdsvis nye og velholdte med laminerede lysegrå plader og åbne hylder nedenunder. Stolene formgivne for en sund siddestilling og med stålrørsben. Opslagstavler til tegninger, udklip og informationer. Der kunne mørkelægges de fleste steder til filmforevisning. Der kunne trækkes landkort ned fra loftet til brug i forskellige fag. Tilsyneladende manglede intet. Ikke engang atmosfæren af skole.

Da mit ærinde var udrettet, gik jeg den lange vej tilbage til hovedindgangen og passerede undervejs flere sideganges udmunding, kontorer, toiletter og nåede den smukke forhal med store grønne planter. Helt til loftet rakte de fra de anlagte jordbede, der var indrammet med brede tremmer af trykimprægnerede brædder. Videre gik jeg, ud gennem dobbeltdørene af svært glas og kom ud på et vældigt asfalteret areal med rader af lærernes biler, der skinnede i alle regnbuens farver. Bag skolens bygninger lød der festlig larm fra frikvarteret. Lige så broget $\mathrm{i}$ toner, som bilernes kulører.

Denne tilsyneladende sorgløse, frie larm var nøjagtig som det frikvartersspektakel, der har lydt i ørerne, lige fra mit syvende år til i dag. Herfra var tankespringet ikke langt til de forskellige skoler, jeg har frekventeret livet igennem.

Det begyndte en mørk, våd januarmorgen i 1923 i Frankrigsgades Skole i København. Efter nogle år her fulgte den noget aldrende og slidte byskole $\mathrm{i}$ Nykøbing Falster og derpå latinskolen sammesteds. 
I 1935 var det slut med skole. Det næste blev uddannelse, og på en måde lignede den tids uddannelse særdeles den højere skoles undervisning. Efter et forsøg på Frøbelhøjskolen endte jeg i lærerstudiet, på Haderslev Statsseminarium, selv om jeg ville have forsvoret det. Man kan roligt forbigå seminariets lokaleforhold i tavshed. De kunne kun præstere ét »klasseværelse« af kvalitet. Biblioteket, hvor danskundervisningen foregik. Hvilket afstedkom, at dette kun kunne bruges om eftermiddagen, tit først efter kl. 15. Så meget større udfordring var der til lærerens personlige betydning, til undervisningens kvalitet. Og der var da enkelte, der kunne omdanne de kedsommelige, dårligt vedligeholdte rum til steder, det var værd at komme. Hvis ikke lærerne kunne, var der mange kammerater, der havde gode evner i den retning.

\section{»Lærerspire« i Knud}

I slutningen af 3. studieår fik vi 14 dages ophold på en landsbyskole. Det var første gang, vi skulle ud at prøve skolelivet uden for øvelsesskolens faste rammer. Man ønskede sig en eller anden skole i landsdelen. Seminariet formidlede forbindelsen, og fik man ja, drog man af, og betalte $40 \mathrm{kr}$. selv for logi og kost $\mathrm{i}$ de to uger. Seminariet betalte den anden halvdel. Meningen var, at vi den første uge skulle være iagttagende, holde os lidt $\mathrm{i}$ baggrunden, og den sidste uge selv overtage undervisningen helt på egen hånd. Der skulle skrives en pædagogisk, psykologisk rapport om et af børnene, og denne kunne få indflydelse på vores eksamenskarakter i praktisk skolegerning (dvs. undervisning). Min forlovede Arne og jeg havde ønsket os to naboskoler. Vi fik ja, og kom derud omkring 10.juni 1940. "Min« skole var den énklassede skole $\mathrm{i}$ Knud i Fjelstrup sogn. Bygningen var en lang længe med lærerbolig i den ene ende og skolestue $i$ den anden. Legepladsen var tillige gårdsplads mellem hus og udhus, garage og køkkenhave. Skolestuens langvæg vendte mod syd og gavlen mod vest. Den var lavloftet, og havde gode dimensioner, og var fyldt med faste borde og bænkerækker i forskellig højde til de mange årganges børn. 1. kl. havde deres plads i dørrækken fra oven. Så fulgte 2. årgang bagved. 3., 4. og evt. 5. klasse sad i midterrækken og de to ældste havde privilegiet med at sidde ved vinduerne. De fem årgange mødte $\mathrm{i}$ sommertiden kl. 7 og gik hjem kl. 12, mens de to yngste kom kl. 13, og havde to eller tre timer. Onsdag og lørdag var alle børnene samlede de sidste timer inden kl. 12. En eftermiddag kom en syerske fra omegnen og havde håndarbejde med piger kl. 13-15. Hun imponerede mig ved at sidde $\mathrm{i}$ klassen begge timer på samme stol, tie helt stille og hjælpe pigerne, når de kom listende med sytøjet eller strikkestrømpen. 
Hendes medbragte vækkeur stod på katederet og udmålte højt og lydt tiden i sovekammeragtige sekunder og minutter. Børnene var så stille og tidspunktet så varmt og døsigt, at jeg ikke fatter, man kunne holde sig vågen. Børnene havde dog været i skole fra $\mathrm{kl}$. 7. Og sommeren 1940 havde vi fået pålagt sommertid af tyskerne.

Når vi to unge lærerspirer mødtes sidst på eftermiddagen var det første vi talte om, hvor langt tyskerne var trængt ind og ned i Frankrig. I Arnes skole i Anslet ca. $7 \mathrm{~km}$. borte fulgte læreren med på et detaljeret Frankrigskort. Han flyttede knappenåle hver gang, han havde hørt tysk presse, mere og mere sejrsstolt. Hos os var det ængstelsen, der var fremherskende, og vi unge sortsynede eller realistiske kunne kun grue over udviklingen. Men dagen var jo propfuld af arbejde og alt var splinternyt, lige fra levemåden, der var langt kraftigere - til undervisningsformerne $i$ den ukendte skoleart. På landet var man meget længere borte fra verdensbegivenhederne. Folk havde ikke så mange bekymringer for vareforsyninger og politiske forviklinger. De var så nært forbundet med det daglige: jord og dyr, plantevækst og vejrlig. Det virkede afskærmende, og smittede hurtigt af på os, der foruden alt det, vi var optagne af, også var forelskede.

Skolestuen vendte, så vidt jeg husker, langsiden mod syd. Der var nogenlunde køligt, når vi kl. 7 samledes til morgensang, efter mælkeklokkens kalden. På det tidspunkt havde jeg indtaget en portion havregrød og en kop kaffe i det komfuropvarmede køkken, hvor fluerne var meget nærgående og plagsomme. Første time var fortælletime, enten bibelhistorie eller danmarkshistorie. Lærer Hansen var en ypperlig fortæller, og selv når det var katekismus, der stod på programmet, kunne han gøre sagen til noget vedkommende, uden citatterperi. Børnene havde også lektier for hjemme i bibelhistorie og historie. I hvert fald de ældste årgange. For jeg husker min imponerethed over den appel, hvormed de afleverede stoffet, næsten ordret efter bogen og i en flyvende fart. Det virkede så pudsigt $\mathrm{i}$ forhold til den varme og rolige måde, læreren fortalte og spurgte på. Læseundervisningen var noget kaotisk. Det startede med, at alle børnene var ved at række sig af led for at få lov til at begynde at læse højt. Når én var udvalgt, gik det løs, og udviklede sig efterhånden til en slags fuga, eller kanon, der til slut lignede en kakafoni. Når den første læser var en linie eller så inde $\mathrm{i}$ teksten, begyndte den næste forfra, mens $\mathrm{nr}$. 1 fortsatte hele lektien igennem, og sådan blev koret større og større, og stemmeføringen højere og højere; for det gjaldt om at kunne høre, hvad man selv sagde. Læreren gik rundt og lyttede her og der, rettede lidt et enkelt sted og hjalp. Sidenhen blev næste dags lektie gennemgået årgangsvis, mens de andre skrev staveord eller havde små selvstændige skriftlige øvelser efter et kortsystem. Alle var hele tiden travlt beskæftiget, til læreren betydede, at timen var forbi. 
Børnenes koncentration var fortræffelig, og de kunne læse; men det var tilsyneladende forbeholdt de dygtigste at vide, hvad de egentlig havde læst og gengive lidt af indholdet. - Diktattimen var afpasset $i$ længde efter arbejdet. Jeg lærte at diktere tre forskellige stykker i samme time, og også her måtte man rose børnenes samlethed om deres eget diktat. - Regnetimerne begyndte med taltræning og tabel for alle, og senere nåede en del at gennemgå et hovedregningsafsnit. De øvrige elever griflede løs i deres hæfter, række efter række af regnestykker. Kl, 10 var spisefrikvarter. Læreren og jeg fik serveret to spejlæg pro persona, og et fad smørrebrød, mælk og kaffe. Jeg lagde nogle kilo på i de to uger. Af og til var vi henne og kikke ud af vinduet til børnene på gårdspladsen. Det var sjældent, der var brug for mægling. De sidste timer var forbeholdt biologi, geografi og boldspil. Et par gange, når vejret var særlig dejligt, gik vi ud ad vejene mod stranden og samlede blomster og så på fugle. Vi lejrede os i grøftekanten, når noget materiale var samlet, og der blev fortalt om blomsternes navne og planternes opbygning på en naturlig og hyggelig facon. Man fornemmede lærerens egen glæde ved tingene og børnene. Man befandt sig godt $\mathrm{i}$ hinandens selskab, og det faktum, at børnene tog de uskadte blomster med hjem til skolen og satte dem i vand, fortalte en del om indstillingen til omgivelserne. Første uge var jeg medhjælper. Anden uge bad jeg om at måtte klare det selv. Læreren var ulykkelig over ikke at ane, hvordan han skulle få dagene til at gå. Jeg tror, han tog ud at fiske, sad ovre i udhuset og forsålede familiens sko, gik på havearbejde; men det passede ham bestemt ikke. En eftermiddag tog hele skolen på udflugt til Skamlingsbanken. Forældrene kom hen i skolegården i deres hestevogne. Vi blev fordelt og rullede under hurraråb ud gennem landsbyen. Selve køreturen var herlig. På Skamling gik vi først rundt og kiggede, så blev der lukket op for madpakkerne, og siden legede vi (mest jeg) med børnene, for hvem en sådan tur var en valdig oplevelse. I aftenkøligheden kørte vi hjemefter; en del af børnene faldt i søvn og fik brug for de tæpper, vi havde haft med til at sidde i græsset på. Snart skulle de ha' sommerferie, og på deres lille himmel var der ingen skyer. I stilheden var det umuligt at undgå at tænke på, hvad der foregik $i$ andre af de af Tyskland besatte lande.

Det var et godt og nyttigt bekendtskab, jeg her havde fảet lejlighed til at gøre. Som alle første-gangs-oplevelser kom den til at stå lyslevende for mig: Det lavloftede rum, de slidte borde og bænke, de ivrige børn, den rolige, venlige og bestemte lærer, som hvilede i sig selv og fik dagene til at glide jævnt og stabilt. Et menneske, der kunne fylde en skolestue med en atmosfære af tryghed og virksomhed på et overkommeligt plan. 


\section{Enelærer i Solderup}

Efter endt eksamen 1941 gik jeg i gang med dagligdagen i folkeskolens byafdeling. De forskellige bygninger og lokaler, jeg kom til at arbejde i adskilte sig ikke væsentligt fra dem, jeg havde færdedes i som elev. Derfor er det kun rimeligt at springe frem til eftersommeren 1950, hvor jeg tog det store spring ud i det uvisse: Jeg blev enelærer i en lidt afsides beliggende landsby.

Det blev til Solderup, ca. $12 \mathrm{~km}$. øst for Tønder. En septembereftermiddag med sol og byger gik vi ind i det tomme skolehus. Boligen lugtede muldent; der var den sommer blevet indlagt elektricitet i landsbyen; så lys var der, men ellers ikke mange faciliteter. Men huset var rummeligt, og dagligstuen med flisekakkelovnen, de franske vinduer og udsigt til en forsømt have med langhåret græs og fem bøgetræer i række imod vest, fyldte mig med lyst og iver. Her kunne blive aldeles dejligt $\mathrm{i}$ de stuer, tænke jeg. Huset råbte på beboere. Vi svarede med $" J a$, nu kommer vi«. Som næsteneste søgte jeg embedet og fik det, og således gik det til, at jeg den 1.november med min cykel og en madpakke tog morgentoget østpå fra Tønder.

Det var lyst, en kold, frisk, klar novembermorgen med rim i græsset og rød himmel forude. Da toget ved den første landstation bremsede glidende op, stod jeg parat ved skydedøren, fik fat i min cykel og satte mig op. Det var fingerkoldt, men herligt. Da jeg kørte op mod Hostrup kirke, kom jeg lige tids nok til at høre solen blive ringet op. Klokkerens kone stod på kirkegården

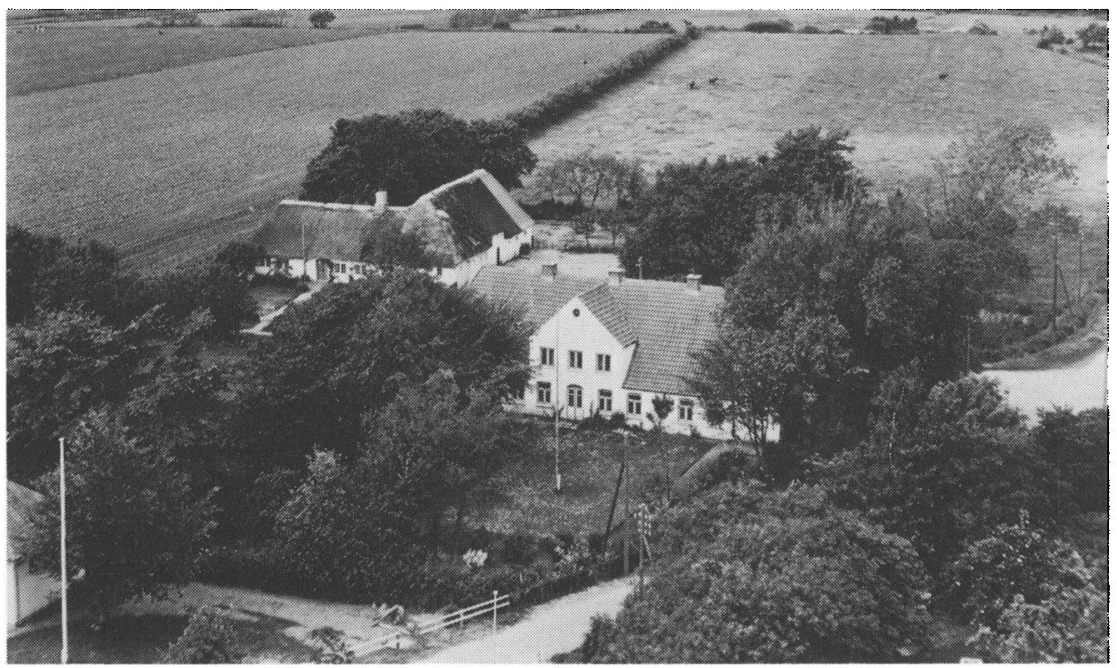

Solderup skole set fra luften. Foto omkring 1953. Privateje. 
neden for tårnet og trak i klokkerebet. Jeg drejede bort fra asfaltvejen ved kirken. "Solderup $3 \mathrm{~km}$ « stod der på skiltet. Jeg fik fart på. Ved indkørslen til landsbyen blev jeg modtaget af de høje elmetræer ved de to yderste gårde. Solen glødede gennem træerne for den anden ende af landsbygaden. Et lille samfund - en lille by. Uden for skolen hoppede jeg af og staldede min cykel ind ved siden af de fire børnecykler, der stod og faldt over hinanden i det dårlige stativ under halvtaget. Døren til tørveskuret, der var nabo, stod åben, og børne-wc'et stank. Affaldskummen af cement til venstre for skuret manglede dækslet, og det røg varmt op af den. Dér blev wc-spandene tømt én gang ugentlig, og med optimisme søgte man at dække med asken fra skolestuens kakkelovn. Det nåedes lige til næste lørdag.

Døren til skoleforstuen stod på vid gab. Jeg så mig om: Ingen dørtrin, lappet, rødmalet cementgulv, ingen vaskekumme; nogle knager med enkelte klædningsstykker, en umalet vindueskarm. Ingen børn udenfor, men indefra en livlig snakken. Mit hjerte slog en lille kolbøtte, da jeg bankede på døren til klassen. - 15 børn var forsamlede om en gammel høj kakkelovn, hvis tromle rødmede svagt og varmede en halvkreds op ud i det lavloftede rum. 15 par ben i gummistøvler, træsko eller almindelige sko havde allerede sat deres spor på det sikkert nyvaskede gulv. - Tavshed. - Et par smil, - mest nysgerrig, mut sejghed. - "Goddag børn. Nå, her holder I til. Ja, I ved jo nok, hvem jeg er. Nu vil jeg gerne vide, hvad I hedder.« - Vi begyndte dagen med en af Kingos morgensange. Fire af børnene kunne læse og synge den sammen med mig. Resten gjorde hvad de kunne. Det lød blandet og musikalsk var det grueligt. »Jeg i mit kald og stand « - en lavloftet, mørkbejdset skolestue, lugt af våde støvler og stald, lidt varme, lidt mulden lugt fra bøgerne $i$ biblioteksskabet, et hjemmelavet Palæstinakort (ganske fortrinligt forresten), et laset Danmarkskort, en ubrugelig symaskine, en revnet murtavle og en fritstående dito på trebenet stativ, en ubekvem katederstol, 15 børn i alderen 7-14 år, mange med »lange« næser, noget sjuskede i påklædningen for nogles vedkommende - »min Gud og Fader kan tilbørligt dyrke«.

I første frikvarter gik jeg ind $\mathrm{i}$ køkkenet bag den private forstue (et koldt og fugtigt rum forresten med en øde knagerække og et orangefarvet, ubestemmeligt tapet, der ikke ville klæbe rigtigt til i hjørnerne). Gulvet gyngede let under ens trin. En udgangsdør mod nord med matte glasruder i den øverste halvdel. Den velsignede varme slog mig i møde, da jeg lukkede døren til køkkenet op. Netop så bragende hed, som man kunne ønske sig efter den frastødende temperatur i forstuen. Der var temmelig mørkt i det rummelige laboratorium. Komfuret stod selvfølgelig længst borte fra vinduet, og ingen lampe var opsat over det, så man måtte nok bruge håndlygte $\mathrm{i}$ vintertiden, når man skulle konstatere, om kærnemælksuppen nu også virkelig kogte. 
Ovndøren stod åben og derudfra kom en god krydret lugt af vådt optændingstræ til næste dags opfyring. Det var mægtig pænt af konen, der sørgede for rengøring, at hun havde fyret for mig. Jeg lagde min madpakke fra mig på bordet og bestemte, at jeg næste dag ville lave mig en kop te til at muntre mig med. Da jeg efter anden time kom derud igen, smuttede en lille grå skabning som et lyn ind ad den åbne ovndør. "Nå, så her er da allerede beboere, « tænkte jeg højt - »hvad mon den lever af?« - Ja, den dag bjærgede den let føden. Den havde gjort et så synligt indhug i min mad, at jeg måtte opgive pakken og fouragere hos høkeren på hjørnet.

Den nye tid var kommet til Solderup sommeren før jeg kom. Efter mange stormende møder, hvor tiltaleformen mellem deltagerne havde bevæget sig fra "Gamle ven« og "Pjatrøv«, som nogle af de beherskede udtryk til kraftigere navne, havde man vedtaget at tilslutte sig elektricitetsnettet. Kun ét par meget aldersstegne folk havde pure nægtet at indlade sig på sligt moderne pjank, og vedblev med petroleumslamperne. Denne vinter var den første med »rigtigt« lys i skolen. Springet fra halvmørke timer med fortællefag til stofrøret i loftet var et helt generationsskift. Det grelle, lilla lys fra stangen under loftet var sandelig ikke smukt, men praktisk. Der var også indlagt vand i skolen. I køkken og bryggers var der en vandhane, og yderst mod øst, bag bryggerset var indrettet et badeværelse. D.v.s. der var et wc med træk og slip, navnlig træk, og en vandkumme, hvor der optimistisk var hane både til varmt og koldt vand. Betingelsen for at dette fungerede var, at vi selv ved hjælp af en affældig vrikkepumpe fyldte en stor galvaniseret vandbeholder, der stod på loftet. Før vi havde pumpet vandet op fra bryggerset, kunne det ikke løbe ud af hanerne. Zinkvidunderet var en for længst kasseret beholder fra præstegården, og den manglede låg. Lige til højre for den var brændslet placeret; koks i én bunke, dårligt skovtræ i en anden. Det første støvede stærkt, det sidstnævnte husede mange insekter, der livede op eller udviklede sig ved at komme under tag. - Imidlertid, hvis vi daglig pumpede ca. 1000 slag med pumpen, havde vi faktisk rindende vand til dagligt forbrug. Den første måned tog jeg frem og tilbage med tog og cykel og følte mig kastet ind og ud i en fremmed, ukendt, lidt ængstende tilværelse. Når jeg kom hjem, var det kun bøgerne i tasken og den tomme madkasse, der beviste, at den eksisterede. Jo, og så de nye gardiner, der blev indkøbt og syet på min maskine.

Skolehuset var en smuk bygning i røde mursten med et godt nyt og tæt tegltag. Det vendte sin pæne facade mod syd til haven og vejen udenfor. En frontispice prydede midterpartiet. Inden for denne var indrettet et stort værelse med kakkelovn og rasende utætte vinduer. Der måtte sættes vandfade parat til opvridning af de klude, der blev lagt i karmene, når efterårsregnen slog ind gennem sprosser og fuger og drev ned ad karme og tapet. Trappen fra det 


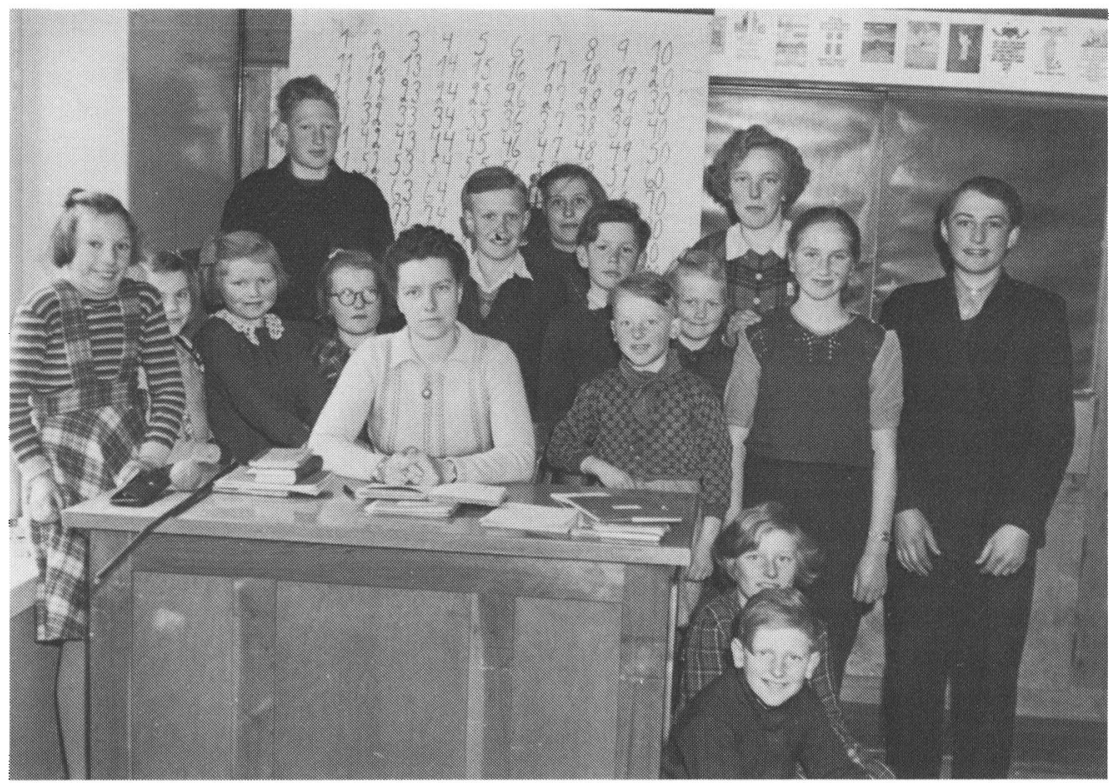

Nina Langkilde på katederet $i$ Solderup skole 1951. Alle elever $i$ skolens syv årgange finder let plads omkring klasselarerinden. Det er striktrejernes, de hvide kravers og de skotskternede kjolers tid. Foto i privateje.

store loft førte ned $\mathrm{i}$ skoleforstuen, og herfra kom man så ind i privaten gennem den tidligere omtalte entré. Tre gode stuer lå på rad mod syd, og disse fik alle deres varme fra flisekakkelovnen, der stod i væggen mellem de to største rum. Var den først varm, kunne vi med lethed klare i hvert fald de to rum med god varme.

Den 1.december kørte i snesjap og søle en stor flyttevogn fra vores andelshus i Tønder ud ad landevejen de $13 \mathrm{~km}$. til skolen. Vognmand Jensen måtte gå det meste af vejen og lede det dobbelte forspand heste. Imens havde jeg forberedt ankomsten til det nye hjem. Fyret godt op og købt en hyggeligt udseende stor vandkedel til komfuret. Blå, naturligvis. Der skulle uden tvivl kaffe til efter den tur. Vores søn fejrede flytningen med en strygende halsbetændelse. Lægen havde tilladt os at køre ham ud i taxa med dyne, og straks efter ankomsten en penicillinindsprøjtning ved sygeplejersken. Katten skulle også køre i bil. Hvordan det skulle gå, var ikke godt at vide. Skolebørnene havde fået fri efter de første to timer. Fra kl. 11 var de fast stationeret på hjørnet i pløret ved høkerens butik. De havde forhørt sig om flyttelæssets ankomsttid. Af og til susede et par spejdere ud af byen for at se efter sensationen. De ventede flere timer; men deres humør slog godt til. De frøs. Så legede de 


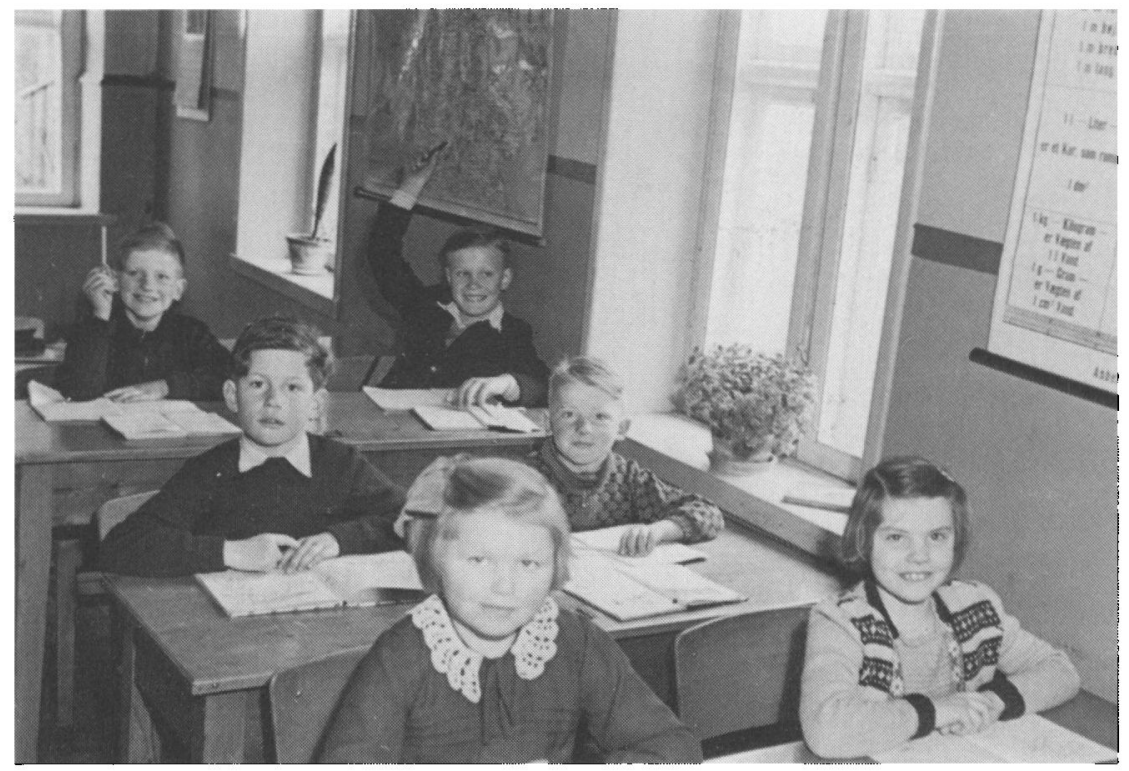

Udsigt fra katederet i Solderup skoles lille klassevarelse i 1951. Villighed og opvakthed lyser ud af de dbne ansigter. Pd̊ vaggen det lasede Danmarkskort og en oversigt over mål og vagt. Foto i privateje.

"Sortemand « for at holde varmen. Vi har aldrig følt os som så store personligheder, som da de fire, tunge heste stred sig om hjørnet i den bløde vej, dampende, under piskesmæld og tilråb og afleverede flyttevognen uden for indgangsdøren mod nord.

Vort beskedne bohave må have skuffet de kæmpeforventninger, læsset havde frembragt hos byens ungdom. Møbler revet ud af deres sammenhæng ser usigeligt fattige ud. Solblegede bagklædninger på ellers anselige lænestole, kommoder, med to eller tre ben, som til dagligt pynter i tilværelsen. Men Idas hvide dukkevogn oprejste familiens are. Da den blev løftet ned af bagsmakken, gik der et suk gennem den lille skare. Alle pigers stille drøm! Og inden $\mathrm{i}$ den en stor karakterdukke med porcelænshoved, brune øjne, lange øjenvipper under det ægte pandehår, røde svungne læber og leddelte arme, hænder med fingre - nogle da. Ida skulle nok få legekammerater.

Skolearbejdet havde den første måned bestået $i$ at finde ud af de enkelte børns standpunkter, ikke ved prøver, for det var helt ukendte ting, men ved at udstyre dem med forskellige læsebøger, som jeg lånte eller fik overladt fra øvelsesskolens udgåede lagre. Det var kun de ældste af eleverne, der virkelig kunne læse og forstå en tekst, men på grundlag af undervisningen for første 
skoleår (lyd og stavemetoden) som jeg tog hele koret med ind i i begyndelsen af hver dansktime, lykkedes det efterhånden at få skred i udviklingen. Og da børnene fandt fidusen, var de ikke så længe om at komme på ret køl. Undervisningsmaterialer var der ingen af; men en tavle og et stykke kridt kan udrette meget. I regning var standpunktet langt mere normalt - når vi blot holdt os til de rene talstykker. I begyndelsen var jeg meget skuffet over fortællefagenes ringe udbytte. Børnene sad ganske vist altid stille, mens jeg fortalte; men deres ansigtsudtryk forandrede sig ikke en smule undervejs, selv på de mest spændende steder. Til alt held fortalte en af forældrene mig engang, at de ikke kunne få ro til at sove om aftenen, fordi deres dreng holdt dem vågen $\mathrm{i}$ sovekammeret med referat fra sagnhistorie og bibelhistorietimerne. Det trøstede mig.

\section{Juletræsfest i forsamlingshuset}

Et par dage ind i december blev jeg stillet over for et nyt krav. „Juletræsfest«. Som den stakkels bybo jeg var, forstod jeg først ingenting af den forblommede tale om at samle penge ind. Men venlige børn satte mig ind i forholdet, og jeg forstod, at jul uden juletræsfest i forsamlingshuset, arrangeret af læreren, var utænkelig. Vore egne børn forberedte sig på det ubegribelige, det nye: Juletræ med julemand og godteposer. Vi måtte have en kort dogmatisk samtale om julemanden, hans eksistens og berettigelse. - Og så gik det løs. - To af de aldste skolebørn gik fra hus til hus og samlede penge ind, og i skolen indøvede vi en eventyrkomedie med rollefordeling efter lodtrækning. De små lærte en dramatiseret sangleg, og alle blev klædt ud. Det var meget vigtigt! Første år måtte jeg fastsætte festen til mellem jul og nytår. Men de andre år blev den afviklet 22. december om aftenen.

$\mathrm{K}$ l. 18.45. Lærerinden kommer, let stram, men smilende over i forsamlingshuset med de sidste sikkerhedsnåle til en forulykket dragt og endnu et par stager til bordene i salen. Folk er begyndt at ankomme. De står og pakker børn ud $i$ den dårligt oplyste forstue. Fra salen høres mumlen, og lidt lunken varme og røg trækker ud, da døren går. Den lukker dårligt, den dør. Den slår sig stadigvæk. Det gir bundtræk. - Der hilses på fra bænk til bænk. Jeg prøver at huske småbørnenes navne og at rose det fine tøj og de nye sko. Mødrene vogter på mine ord og børnene på mine øjne. Hvem er mon mest ængstelig? Damen fra byen eller den tavse, benovede unge med det ubevægelige, renskurede ansigt og den struttende kjole? De bare arme og de kolde pusselanker i hvide strømper?

Det mørke træ i hjørnet ænses næppe. Det er ellers smukt, foræret os fra 
præstegårdens plantage, pyntet med alt det tingeltangel, som lå i kassen på loftet fra de andre år. Det dufter dejligt nu i den begyndende varme. Man er optaget af andre ting. 71/4 opgiver man at vente længere. Skolebørnene kan ikke være stille længere bag scenen, de små i salen heller ikke. Vi synger "Velkommen igen, Guds engle små«, og der bydes velkommen. Jeg gør et forsøg på at sige et par ord om Kristi fødsel under stadige forstyrrelser fra indvandringen bag i salen. Så en salme, mens mange taler hojlydt sammen. Tæppet går. Nu er det kun de mindste årgange, der forstyrrer. Men det til gavns. De små amatører fremfører det lærte helt pænt, men en del drukner i to-åringers råben-op og tre-åringers gentagne løben op til rampen i trods. Heldigvis mærker skuespillerne ingenting, og deres forældre fryder sig ubetinget. Instruktøren har ikke tid til at opdage noget somhelst, og hendes mand prøver at formå mødrene til de små at holde på deres afkom. Tæppefald og velvilligt bifald.

Store, svære, rødmossede Signe har kaffen parat. Folk har deres bagværk med i pressede glasskåle eller farvestrålende kagefade i tysk smag; men kagerne er alle sønderjyske. Der er mange slags. Fedtkager i hvidt og brunt, rugmelsknebkager, fedtebrød med kokos og glasur, mandelkranse, små tyndtskårne sirupskager med mandler $\mathrm{i}$ dejen, vanillekranse, kokoskranse, kys for både hvide og brune, finskbrød, jødekager. Og så er der æblekagen med flødeskum, måske marmorkage. Børnene hujer rundt en stund. - Nu må der leges, for ellers overlever vi ikke. Træet tændes, vi går rundt i flere kredse, slår hurtigt over i verdslige toner og så kommer - oh, store rædsel og fryd! Julemanden! Jeg havde da husket at spørge Asmus om lov til at låne hans kørepels, fundet masken på loftet $o g$ bedt Bernhard Sommer om at være regissør og julemand. De 40 poser, fyldt med godter (ved min hånd), repræsenterer indsamlingsresultatet. Over $100 \mathrm{kr}$. Brugt til slik! Gud give, man nu har fảet fyldt dem helt ens; og blot man nu har tydet folks navne og børneantal på den næsten ulæselige liste, der blev leveret tilbage efter at have været ude $i$ sne og slud. Tre poser har man i reserve. For sæt der mangler nogen, eller der kommer flere børn, end man har kunnet vente. Og sæt de nu bliver til overs. Det er lige så galt! For så er der for mange. Hvad gør man med dem? Slik kan ikke byttes, og de må frem for alt ikke havne i lærerbørnenes maver. Det er jo betroede midler!

Med ens sidste stemmekraft leger man "Tornerose«, "Enebærbusk " og "Haren sad i grøften«. Kl. 21.30 beder jeg skolenævnets formand om at slutte. - »Æ sæjer tak til jer oll -«. »Glade jul«. - Den synges i opbrudsstemning. Nogle fædre er gået ud at skaffe kørelejlighed eller varme motor op, eller ringe til vognmanden i Hostrup. De mindste sidder med fortinnede øjne og stivansigtede af slikkeri og sløver på mors skød. Skolebørnene synger rigtig 
pænt med. - God nat - og glædelig jul! - Salen tømmes lidt efter lidt; den ligner en bule.

Jeg samler stagerne fra bordene og henter mine egne lyseholdere fra juletræet. Jeg orker ikke at se derover i morgen. Min mand er gåt hjem i forvejen med vore børn. - „God nat, Signe og tak for dejlig kaffe. Ja, nu er der noget at gøre for dig her i morgen.«

\section{Skolen fejrer guldbryllup}

Denne samlede aktivitet, der omfattede både dansk- og tyskorienterede hjem, var ikke speciel for denne skole. Det samme fandt sted overalt omtrent på samme dag og tid i alle skoler eller forsamlingshuse. Det var blot for mig, det var nyt. Der blev meget at lære og opleve for os, der kom fra byen. De havde en smuk skik: Når der var guldbryllup i landsbyen, eller en høj, rund fødselsdag, kom skolebørnene hen til festhjemmet og sang morgensang for de gamle. Jeg ser endnu for mig, børnene. Efter at ha' hejset flaget $i$ haven, gik de ind og vaskede hænder $i$ de to vandfade, jeg havde fået kommunen til at bevilge. De stod på en vaskebænk, som sognerådsformanden selv havde snedkret til os. Imens havde jeg været $\mathrm{i}$ haven og plukke tulipaner, eller påskeliljer. Så gik vi i sluttet trop over skoletoften til vore naboer, hvor der var guldbryllup, hvert barn var udstyret med en blomst $i$ hånden og havde fået besked på, at den skulle afleveres til bruden med et buk eller en nejen og et "Te løk mæ æ dav«! Så fulgte »Det er så yndigt« i blandet kor, og bagefter en bevæget tak under blanke tårer fra den til daglig noget strenge, gamle kone, der ofte fra sit køkken holdt udkik med, om hendes børnebørn led overlast i frikvartererne. Dernæst servering ved bukkebordet fra forsamlingshuset: Saftevand og boller. Senere kvad vi igen på opfordring en sang fra højskolesangbogen, inden vi gav hånd til farvel og tak, og børnene myldrede ud på skolepladsen og tog sig et godt frikvarter, mens lærerinden fik sig en kop kaffe ekstra.

Om eftermiddagen var der efter gammel skik en ganske kort gudstjeneste for guldbrudeparret og familien i den smukt pyntede kirke. Jeg beklædte stillingen som distriktskirkesanger, og forestod ved denne lejlighed salmesangen. De to gamle folk sad foran alteret i de samme bryllupsstole, de havde siddet i for 50 år siden. Efter en kort tale var der altergang og så en afsluttende salme. Om aftenen var der middag for familie, hvor også lærerens var indbudt, og kl. 8 fyldtes salen med så at sige resten af byens beboere. Kaffebord og sang efter den blå sangbog, og så kom punchen ind i de afskyllede kaffekander, der blev stillet op, og dansen tog fat, så det gungrede. I to lænestole sad 
brudeparret, og sandelig om ikke brudgommen dansede et par omgange med sin brud. Lidt senere bød jeg ham op til en rheinlænder, og vi tog en tur, salen rundt. Han tog mig med hen til sin plads og anbragte mig på sit skød. Han var en meget døv og skrøbelig mand at se til. Havde været i verdenskrigen og krigsfange hos russerne. Nu sad han med mig om livet, og gentog atter og atter "Åh, ja - åh ja«, mens han trykkede mig fast med sin arm. Det huede ikke bruden. Jeg blev et stort minde rigere, mens jeg prøvede på ikke at tynge for meget.

\section{Aftenskole og dilettant}

Om vinteren var der selvfølgelig også aftenskole. Konerne fik hjælp til syning af kjoler og bukser til sig selv og børnene. En uddannet syerske underviste dem, og man prøvede på at opfylde de krav til almen håndarbejdsundervisning, der krævedes fra myndighederne for at få tilskud til foretagendet. Det kunne knibe her og der med at skaffe fremmøde i tilstrækkeligt omfang. Til det "finere" håndarbejdskursus en ugentlig eftermiddag, også kaldet "Køn syning«, måtte jeg melde mig for at kurset kunne afholdes. Vi var jo få, men hvor var det vigtigt, at det kunne blive til noget. Også her havde jeg meget at lære, ikke blot fagligt, men det var væsentligt for mig at møde konerne på lige fod, og de morede sig kosteligt over mine ringe evner i syning, og at se mig $i$ elevens rolle. Jeg nåede ikke langt, men eftermiddagene var yderst fornøjelige. Kaffepause havde vi selvfølgelig, og så gik snakken endnu mere livligt sammen med larerinden.

Fra skolen udgik på en måde også initiativet til dilettantspillet, idet en af os var formand for den selskabelige forening, og man gik som en selvfølge ud fra, at vi kunne stå for indøvelse, kulisser, dragter. Vi øvede os rundt i hjemmene, og for os alle var det et ret stort arbejde, der gik forud for opførelsen ved fastelavstide i forsamlingshuset.

\section{Hverdag i skolen}

Dagligdagen i skolen var nu det vigtigste. Hver dag havde jeg et program for undervisningsforløbet, og hver dag skete der uforudsete ting undervejs, der mere eller mindre kuldkastede mine planer. Så måtte man være smidig. Syv forskellige årgange under én hat! Jeg forsøgte at anvende det bedste, jeg havde oplevet i min tid som seminarieelev i landsbyskolen; men jeg havde ikke lærer Hansens rolige, urokkelige indstilling til forløbet. Desuden stillede jeg andre 
krav til mange af fagenes udformning. Som helhed overholdt jeg timeplanen, men forlængede eller afkortede lektionerne efter behov. En fortælletime kunne kortes af efter stofmængden og interessen,mens f.eks. regnetimerne kunne trække ud, hvis børnene nu var så godt i gang. (Jeg har altid undret mig over dette fags tiltrækning og evne til motivation). Vi drev emneundervisning for de tre ældste årgange, således at vi behandlede et område i flere fag, f.eks. "Romerriget«. Jeg fortalte om guderne fra Oldtiden, sagn og myter. Vi gennemgik Italiens geografi, skrev diktater med indhold fra det historiske stof. De tegnede kort og udstyrede dem med navne, de tegnede billeder til de fortællinger de havde hørt, vi snakkede naturformer, landskaber og dyreliv. $\mathrm{Al}$ den slags var helt nyt for børnene, og så vidt jeg husker, gik arbejdet fra hånden med lyst. Materialer fik jeg fra tid til anden, navnlig til dansk og regning, men vore landkort var så forældede og lasede, at det kunne knibe at følge flodforløb uden at pegepinden hang fast her og der. De nuværende grænser var svære at fastholde på grund af kortets alder. Det bedste ved det hele var, at de fleste børn fik mod på at læse selv efterhånden, og bogudlånet fra biblioteksskabet steg. Vi var begyndt $\mathrm{i}$ de første måneder med at se billedbøger. Vore egne børns bøger kom ind i klassen, og de sidste ti minutter af dagen brugte jeg til at vise og forelæse en eller to billedbøger. Det var beregnet for de mindste; men interessen viste sig at være lige så stor hos de ældre børn. De samledes oppe foran katederet, de små forrest, de større bagved, de sidste sad på et bord. Så kunne alle se og høre. Heldigvis havde jeg læst teksterne så ofte, at jeg kunne dem udenad. Og det er væsentligt, særlig da mange var på vers. Det var en stor fryd at gøre børnene bekendt med de klassiske billedbøger. Senere læste jeg højt, og altid for et taknemligt publikum. Til biblioteksskabet fik jeg efterhånden indkøbt et par nyere børnebøger, og vi fik en fast lånedag. I hjemmene rundt om læstes der ikke mange bøger; men $\mathrm{i}$ vinterperioderne, når flere fædre var arbejdsløse, kunne bogskabet ikke klare efterspørgslen, og vi tyede til vore egne reoler. Det var også svært for mig at vide, hvad jeg skulle udlevere til de voksne. Oftest var det nemlig ikke dem selv, der kom. De sendte et barn af sted for at låne "en bog«. Havde man så truffet helt ved siden af, kom bogen hurtigt retur: Den var der ikke noget ved! Havde man varet heldig at ramme smagen, ville de gerne have en af samme slags. Så vidste man bedre besked.

Nogle af de mest intime stunder var håndarbejdstimerne om eftermiddagen. Pigerne fra og med anden årgang mødte op længe før vi skulle begynde. De fleste kunne allerede hjemmefra lidt. Nogle få kunne strikke, nogle kunne sy dukketøj af stofrester, en enkelt kunne hækle; men jeg lagde nok lige lovlig megen vægt på, at de skulle udføre de forskellige teknikker på den "rigtige« måde. Det var nu god latin dengang, og børnene syntes stort set, det var $\mathrm{i}$ 
orden at gøre som jeg sagde. Drengene misundte pigerne de timer, hvor tonen var langt mere tvangfri, end når vi sad og skulle koncentrere os om hver sin boglige opgave. Så fik de lov at være med, på den betingelse, at de virkelig ville lære noget, de kunne få brug for. De kom. Og hvor de sled! De lærte først at sy knapper $i$, dernæst at stoppe strømper. De var meget ihærdige med at lære at strikke. Det var til stor undren, at det gik så fint. I december måned lavede vi julegaver til deres forældre under udfoldelsen af stor hemmelighedsfuldhed. Så blev timetallet udvidet, og da vi også indøvede komedie og skulle have tid til morgenhygge med adventskrans og julesalmer, er det ikke mærkeligt, at den måned står $\mathrm{i}$ erindringen som årets travleste.

Gymnastik var et fag, jeg savnede meget. Ganske vist bevægede børnene sig langt mere, end de gør nu til dags. Mange havde en lang skolevej; var det dårligt vejr, eller hård vinter, kunne turen være drøj. Men én ting var sikker: At de, der kom længst borte fra, var de første i skoleforstuen, og aldrig kunne de drømme om at forsømme skolen på grund af snestorm. Så tørrede vi vanter og huer inde $\mathrm{i}$ varmen, og gummistøvlerne stod i køkkenet i komfurvarmen i timerne. Om sommeren spillede vi flittigt rundbold på den græsklædte skoleplads, og et forår lånte jeg en plint og en buk ovre i forsamlingshuset, og lod dem øve sig $\mathrm{i}$ at springe. Højdespring kunne vi også dyrke - alt i det små. Nogle vintre tror jeg, vi gennemførte ti minutters skolestuegymnastik hver dag. Jeg havde læst og set lidt af, hvordan skolebordet kunne udnyttes til smidighedsøvelser, og børnene syntes, det var helt sjovt at komme lidt op og røre lemmerne. Det gav varme i kroppen, og da kakkelovnen ikke var særlig effektiv, kunne det nok behøves på kolde dage. Navnlig var den sendrægtig om morgenen. Der skulle fyres op $1 \frac{1}{2}$ time, inden skolen begyndte, hvis vi skulle opnå 16 grader. Til sidst fik jeg den kasseret. En fagmand fra Tønder kom derud, og til min glæde erklærede han ovnen for totalt opslidt. Vi fik en kamin i stedet, og så var vanskelighederne forbi.

Så snart lejlighed gaves fejrede vi, hvad der var at feste for. Alle børnenes fødselsdage selvfølgelig, med falles flaghejsning $i$ haven og hurraråb og fødselsdagssang osv. Den dag den første stær tog bolig i skolestuens mur var også en festdag. Over vinduerne bag $\mathrm{i}$ klassen ud mod sydhaven fandtes der to huller i muren. Det så ud, som om der oprindelig udefra var taget en mursten til plads for en bjælkes anbringelse. Bjælke var der ingen af, men et hul, ideelt til redebygning. $\mathrm{Ja}$, der var to. Spurvene søgte tit ly der $\mathrm{i}$ vintertiden, og når stærene ankom, gik det ikke stille af. De smed grossingerne ud og begyndte at sætte bo. Det gav os anledning til mange sange om forår og stære og en ekstra historie. Hulningen var ind til skolestuen lukket med en almindelig træklods. Den sluttede ikke tæt, og i de næste måneder dryssede der dagligt redemateriale ned på gulvet hos os. Så var der den dag, vi hørte de første pip 
fra de nyudrugede unger. Ja, så var det lige før, flaget skulle op. Uden for de samme vinduer stod vores fem bøge. Den dag de første grene hængte deres skære silkeløv ud, var flagdag. Vi tog også af og til en lang tur ad de smalle markveje og over grøfter og hegn til en lille klat skov. Så havde vi madpakken med, og jeg tror, jeg forsøgte mig med lidt botaniseren. Børnene morede sig i hvert fald. Den tydeligste anskuelsesundervisning i biologi, vi fik, var, da jeg en morgen kom ind i skolestuen og opdagede et nyt, friskt muldvarpeskud, lige foran katederet!

Selvfølgelig var det ikke lutter fest og glade dage. Et lille samfund byder tit på beklagelige og besværlige oplevelser. Man kender hinanden allesammen, somme tider for godt. Sammenligningsmuligheder har man ikke mange af. Kritikken og mistænksomheden kan få for godt fat. I vanskelige perioder trøstede jeg mig med, at deres tidligere lærere altid blev omtalt så pænt. Sådan en størrelse ville også jeg blive engang.

\section{Forskolen i Rørkær}

Og det blev jeg. - En landsby i samme kommune, men tættere ved byen skulle skifte lærer. Jeg søgte og fik stillingen. Jeg vidste at "min« skole stod for nedlæggelse i løbet af kort tid. Sommeren 1956 flyttede vi til Rørkær skole.

Huset var i sig selv en seværdighed. Det var bygget i 1684 af bønderne i landsbyen til skole for deres børn. Man havde lånt nogle hundrede rigsdaler af provsten $i$ kirkebyen Hostrup og var gået $i$ gang. Sydvendt ligger skolen med sin høje rejsning af stråtag over den hvidkalkede længe. Langstrakt, hvilende i sig selv $i$ en rummelig have, med roser, kaprifolier og vildvin om vinduer og indgangsdøren i midten af facaden. Krokus og påskeliljer om fødderne i forårstiden. Som luften mildnedes, bredte det gule flor sig mellem buskene og de spirende stauder. Beliggenheden i landsbyen var central, men ikke ubetinget heldig. Haven lå lavt og var meget fugtig, og genboens mødding og ensilagebeholdere kunne ofte betage os lysten til ophold derude. Det var som om eftermiddagskaffen fik afsmag. Men det var gode genboer!

Den østlige afdeling af huset var den ældste. Gavlen bulede ud i bryggerset. Bagved var der den gamle stald med plads til et par køer. Der stod vore cykler og redskaber. Svalerne byggede troligt rede over stalddøren år for år. Kom man fra bryggerset, var køkkenet det næste rum. Det vendte mod nord, havde terrazzogulv og var hundekoldt om vinteren med de gamle utætte vinduer. Men der var plads nok. Den store dagligstue vendte mod syd med fire fag smårudede vinduer og bjælkeloft, hvidmalet. De sidste to fag vinduer i østdelen af huset angav spisestuen. Så trådte man ud i forstuen med indgangsdøren. 


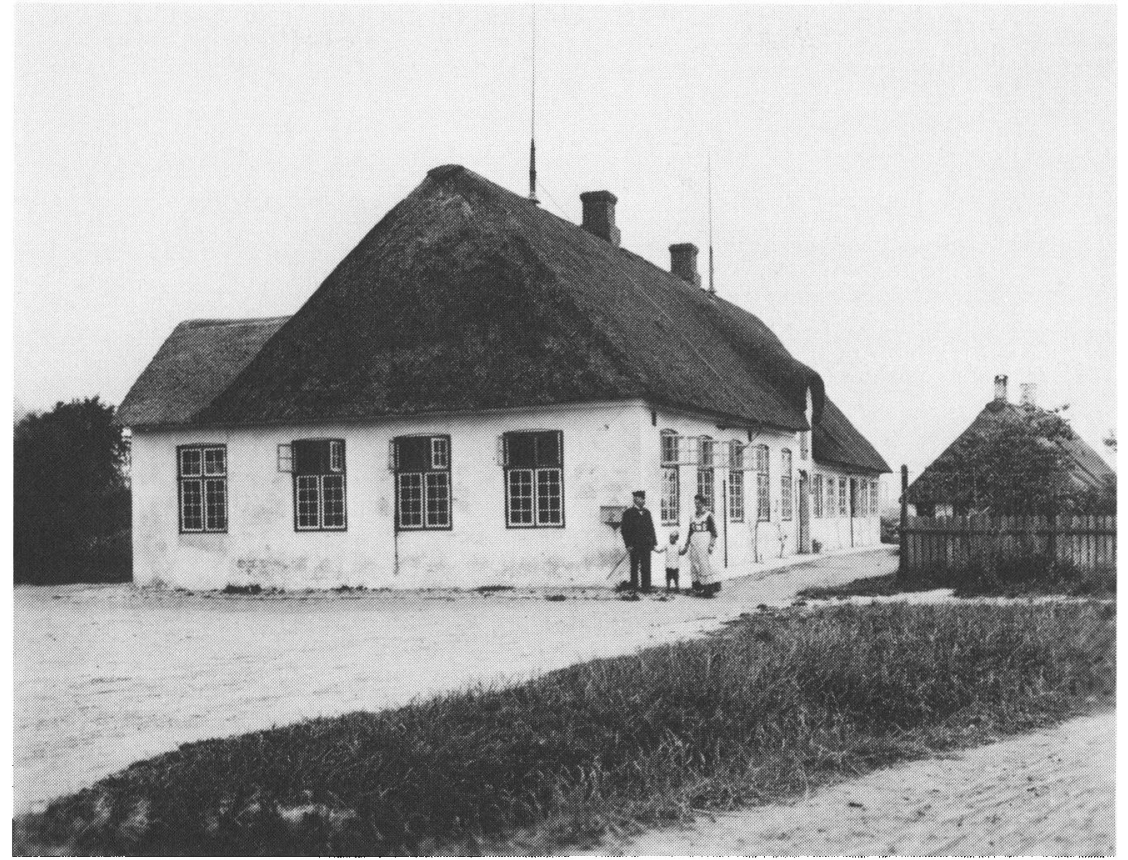

Skolen i Rørkar er her fotograferet i 1910. Vestenden med de store vinduer $i$ skolestuen skiller sig tydeligt ud fra den celdre ostende, som rummede larerboligen. Historiske Samlinger.

På den anden side forstuen begyndte vestenden af skolen. Den lå et trin højere, og var en senere tilbygning, da skolemyndighederne forlangte mere plads og flere $\mathrm{m}^{3}$ luft til børnene. Den rummede vort soveværelse og et kontor og så det vigtigste af det hele: skolestuen med forstue og tilbyggede toiletter. På smukkeste måde var de to dele af huset forenet via en buet kvist $\mathrm{i}$ tagetagen. Det var et hus med personlighed.

På loftet var der i kvisten indrettet et hyggeligt, lidt mørkt værelse. I den høje vestgavl fik vi lavet to små kamre med udsigt til skolepladsen og kastanjetræerne. På grund af værelsernes beliggenhed fjernt fra trappen ned $i$ bryggerset fik vi installeret et knudereb i vinduessprosserne. Egentlig var jeg $i$ alle årene lidt urolig ved at have børn og hushjælp liggende deroppe. Hver gang det blev nattetorden, blev de beordret nedenunder.

Det blev gode år i Rørkær. Skolen havde været en énklasset skole, som den i Solderup, men nogle år tidligere var den blevet til forskole, med tre årgange.

Nu kunne jeg samle mig om et mindre pensum og få tid til at udforme begynderundervisningen langt grundigere end før. Børnetallet var overskueligt. 


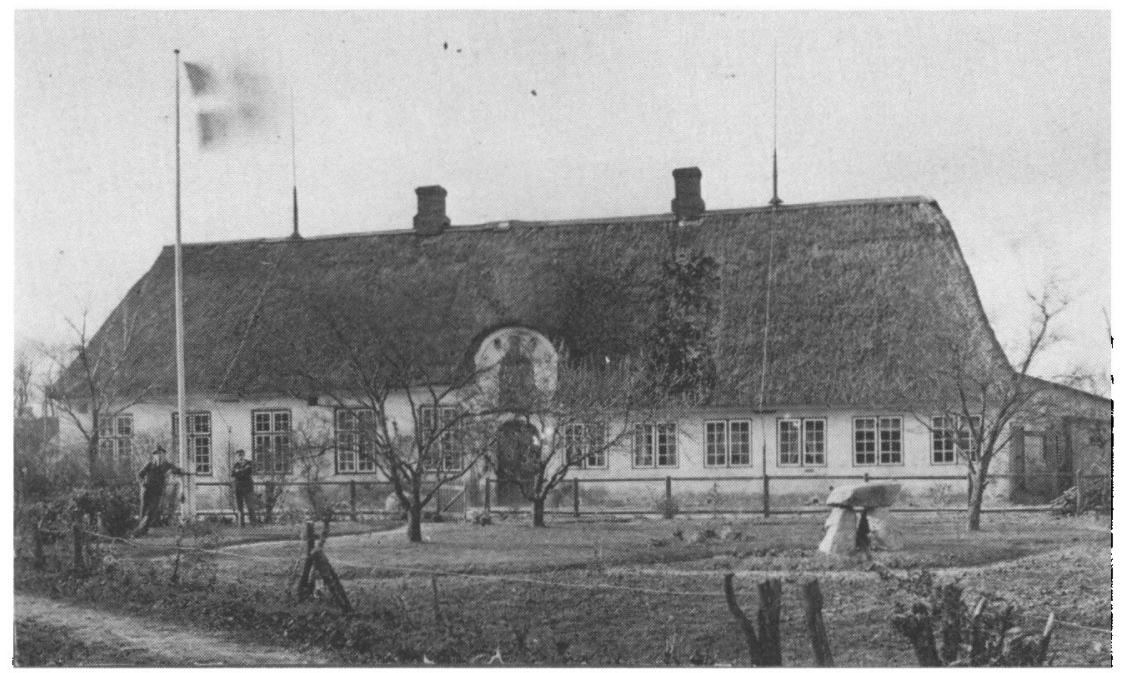

Skolen i Rorkar fotograferet i 1921/22. Ved fagstangen enelarer Niels Juel Billum, som var den forste danske larer efter Genforeningen. Der var på dette tidspunkt 48 elever i skolen. Rorkar skole var bygget $i 1684$ med skolestue og bolig for skoleholderen samt stald til to keer og kålgård. I 1810 blev en mere hojloftet skolestue med store vinduer tilbygget mod vest. Denne del af bygningen blev restaureret i 1856 . Foto i privateje.

Det var let at holde sig orienteret om hvert enkelt barns standpunkt og vanskeligheder. Og som regel kunne man nå at gøre noget for de svagere.

Vi havde selvfølgelig en timeplan. Men lektionerne var af ulige længde. Var der skub i foretagendet, kunne der gå lidt længere tid, inden det blev frikvarter. Så blev frikvarteret også lidt længere, og den næste lektion lidt kortere. Fortælletimerne var gerne lidt kortere end regnetimerne. Vi kunne nå vort stof, og nåede et barn ikke at få lært læsekunsten det første år, havde det jo ingen nød. Det skulle blot nåes inden for de tre år, og det lykkedes altid.

Vi fik efter gentagne ansøgninger en sandkasse på skolepladsen. Pigerne og drengene skiftedes til at bestemme derovre. Drengene lavede veje, tunneller og broer. De havde små biler med og kørte rundt med dem. Pigerne lavede små haver med pinderækværker. De kom med blomster hjemmefra og pyntede op. Det var af pladshensyn de skiftedes. Så blev det jo gammeldags og kedeligt. Men vi brugte den til den første geografiundervisning. En sommer byggede børnene huse på skolepladsen. Drengene kom med gamle mursten og fik en fader til at lave mørtel. De fandt et kasseret staldvindue, sådan et halvmåneformet jernvindue. Det fik de muret i væggen. Vi fandt en blikplade til tag. Pigerne tømrede et hus sammen af træpakkasser. Også her fik vi tag og vinduesåbning. Et par kasser til at sidde på. De malede, så det flød med rester 
hjemme fra forældrenes redskabsrum. Der blev sågar hængt gardiner op. Så sad de og spiste deres mellemmad i husene. Da de ikke gad det mere, eller kom op at skændes om ejendomsret og brugsret blev vi omsider enige om at fjerne husene. Det gik lettest for pigerne!

Vi fik også tid til at spille komedie indimellem, vel nok ud fra dansktimerne. Selvfølgelig spillede vi rundbold i sommerhalvåret.

Det foregik ude på den grusbelagte skolelegeplads, som selvfølgelig ikke havde de rigtige mål, hverken i længden eller bredden. Det var en fordel for de mindste børn, men når vi mødtes med andre landsbyskoler til det årlige idrætsstævne, var det et stort minus. Var vejret fint, samledes der gerne en lille skare småsøskende langs rækværket udenfor. I forsommeren var det givet, at de fleste af de kommende første-års elever var faste tilskuere. Af og til blev de inviteret ind at være med. I øvrigt kunne jeg næsten forudsige, hvilke førsteårs børn, der ikke var skolemodne. Dem så jeg kun til julefesterne og den første skoledag. De kom aldrig hen for at kikke ind til os.

Jeg fik to gode kontakter udadtil. Den ene kom fra en kollega ved en landsbyskole længere mod vest. Hun underviste også de mindre årgange, og opfordrede mig til at vore børn i tredje årgang skulle besøge hinanden på skolen. En lørdag eftermiddag fyldte jeg bilen og kørte derud. Vi havde modtaget de mest fornøjelige invitationer en til hvert barn, fra en kammerat. Da vi svingede ind på deres skole, stod de små værtsfolk parat. De havde bagt boller sammen med lærerinden. De havde dækket borde og pyntet dem i klassen. Der var hjemmedekorerede servietter og hjemmelavede stager med lys $\mathrm{i}$. Så fik vi alle chokolade, og efter at vi voksne havde sat en leg i gang, trak vi os lidt tilbage, så ungerne kunne lære hinanden at kende i fred. Det blev meget vellykket, og mine børn syntes det havde været en dejlig tur. Vi gjorde gengæld efter et passende tidsrum, og det viste sig, at nogle af børnene i mellemtiden havde skrevet breve til hinanden. Det var en stor dag, da vi var værtsfolk.

Den anden kontakt kom fra Vejle forskoleseminarium. Her sendte de hvert forår en klasse studerende på landsbyskoleophold. De fandt frem til min skole, lige pludselig, og jeg fik i nogle år to unge piger ad gangen i 14 dages praktik. For det første var det nogen gave piger, der kom. Dygtige, venlige, med en fin indfølingsevne, parate til at lære og at virke, både selvstændigt og i samarbejde. De tilførte mig nye ideer om metoder og materialer, og samtidig virkede de bestyrkende. Børnene var glade for pigerne, og de havde godt af at mærke, at der var andre end lige deres lærer, der fordrede noget af dem. To af holdene boede også hos os, var på fuld kost og deltog i familiens liv. Samtidig gav det begge parter rig lejlighed til at drøfte undervisningsforløb og problemer uden for skoletiden. Jeg vedligeholdt forbindelsen med dem en tid lang. 
Erindringen er også en slags virkelighed. De ting, jeg i dette afsnit har taget frem, er dem, jeg helst og bedst husker. Begribeligvis var der mørke dage med vanskeligheder for børnene og for mig. Der opstod misforståelser mellem hjem og skole. Sjældent var de værre end at et besøg i hjemmet kunne klare dem. Når vi sidst $i$ juni holdt forældredag - en tidlig aftentime - mødte så godt som alle fædre og mødre op. Vi tog en dansktime, så vidt muligt som til daglig. Børnene læste en smule højt, evt. for nogle af de tilstedeværende enkeltvis. Efter et kort frikvarter, en smule hovedregning og en sang blev børnene underholdt i klassen og på legepladsen af ældre børn. De fik en lille traktering, mens forældrene nød kaffen inde i privaten, og skolenævnsformanden fremkom med den traditionelle tak for skoleåret. Det var hvert år lidt vemodigt at tage afsked med tredje-års-børnene, der nu skulle i centralskolen i Jejsing og fortsætte. I begyndelsen af det nye skoleår kom de af og til hen og stod og så langeligt ind på skolepladsen. Her havde de jo været de store. Nu var de blevet de små det nye sted. Men det varede såmænd ikke så længe, før de med overbærenhed så på deres gamle lærer i Rørkær. Jeg tror, de var af den overbevisning, at jeg ikke kunne eller vidste mere, end det, jeg havde lært dem de første tre år!

\section{Om forfatteren:}

Nina Langkilde, født 1916 i København, datter af sognepræst, senere stiftsprovst over Lolland-Falster stift Hans Nielsen Dreiøe. Larereksamen i Haderslev 1941. Gift 1942 med Harald Arne Langkilde, lærer/seminarielektor Tønder 1944-64, skolepsykolog Sønderjyllands amt 1964-85. 